\title{
The Level II aggregated forest soil condition database links soil physicochemical and hydraulic properties with long-term observations of forest condition in Europe
}

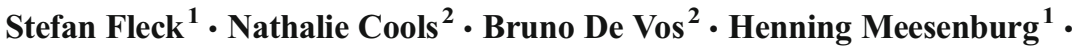 \\ Richard Fischer ${ }^{3}$
}

Received: 31 May 2014 / Accepted: 28 June 2016 /Published online: 11 August 2016

(C) The Author(s) 2016. This article is published with open access at Springerlink.com

\begin{abstract}
- Key message Aggregated, consolidated, and derived soil physicochemical data of 286 ICP Forests Level II plots were completed with soil hydraulic properties for integrated use
\end{abstract}

\section{Handling Editor: Marianne Peiffer}

Contribution of the co-authors Stefan Fleck: writing of the manuscript, analysing and compiling data, metadata description, corresponding author until publication of the manuscript*

Nathalie Cools: analysing and compiling data, writing of the manuscript, metadata description, corresponding author after publication of the manuscript* Bruno De Vos: supervising the project, writing of the manuscript Henning Meesenburg: supervising the project, writing of the manuscript Richard Fischer: writing of the manuscript

Electronic supplementary material The online version of this article (doi:10.1007/s13595-016-0571-4) contains supplementary material, which is available to authorized users.

Nathalie Cools

nathalie.cools@inbo.be

Stefan Fleck

stefan.fleck@nw-fva.de

Bruno De Vos

bruno.devos@inbo.be

Henning Meesenburg

henning.meesenburg@nw-fva.de

Richard Fischer

richard.fischer@thuenen.de

1 Northwest German Forest Research Institute (NW-FVA), Göttingen, Germany

2 Forest Soil Coordinating Centre of ICP Forests, Research Institute for Nature and Forest (INBO), Geraardsbergen, Belgium

3 Institute of International Forestry and Forestry Economics, Thünen Institute, Hamburg-Bergedorf, Germany with forest monitoring data. Database access should be requested at http://icp-forests.net. Metadata associated available at https://metadata-afs.nancy.inra.fr/geo network/apps/georchestra/? uuid=153e599e-6624-4e2bb862-8124386ea9cd\&hl=eng

- Context The ICP Forests database is one of the most comprehensive forest ecosystem datasets in Europe and contains the accumulated results of more than two decades of harmonised forest monitoring all over Europe.

- Aims The aim of this paper is to share knowledge on the ICP Forests Level II soil data for broader use among forest scientists.

- Methods After standard analysis, quality checks, aggregation, and calculation of derived variables (e.g. nutrient stocks, base saturation, $\mathrm{C}: \mathrm{N}$ ratio, and water retention parameters), data have been gathered into a static database (AFSCDB.LII.2.2), which will be updated to new versions as soon as new measurements become available.

- Results The database provides a basis for the combined evaluation of up to 130 unique soil variables of 286 plots with dynamic data on tree growth, ground vegetation, foliar chemistry, crown condition, tree phenology, leaf area index, ozone injury, litterfall, soil solution chemistry, deposition, ambient air quality, and meteorological data assessed on the same plots.

- Conclusion The unprecedented comprehensiveness and level of detail in this newly aggregated database may overcome existing restrictions so far impeding the realisation of largescale forest ecosystem studies in Europe.

Keywords Monitoring $\cdot$ Base saturation $\cdot \mathrm{C}: \mathrm{N}$ ratio $\cdot$ Cation exchange capacity $\cdot$ Available water capacity $\cdot$ Soil water retention $\cdot$ Soil database $\cdot$ Europe $\cdot$ Soil nutrient stock $\cdot$ ICP Forests 


\section{Introduction}

\subsection{European forest monitoring network}

The International Co-operative Programme on Assessment and Monitoring of Air Pollution Effects on Forests (ICP Forests, www.icp-forests.net) acts since 1985 under the Convention on Long-range Transboundary Air Pollution of the United Nations Economic Commission for Europe (CLRTAP/UNECE). The 42 participating countries monitor the condition of forests in Europe on two different monitoring intensity levels: Level I locations are more than 11,000 forested points in a network of grid cells of $16 \mathrm{~km} \times 16 \mathrm{~km}$ over Europe (without instrumentation), and Level II locations are actually 525 comprehensively instrumented plots in selected forest ecosystems across Europe. While the Level I network was constructed as a dense and spatially representative grid of forest sampling points, the Level II is dedicated to in depth investigations on relationships between all relevant forest ecosystem traits and processes in monitoring plots. The plots were selected by national forest institutes for long-term permanent monitoring. The investigations comprise continuous measurement surveys on meteorology, ambient air quality, deposition, litterfall, and soil solution chemistry (about monthly); annual surveys on crown condition, tree phenology, leaf area index, ground vegetation, ozone injury, and foliage compounds; and biannual surveys on foliar chemistry, five-yearly surveys on tree growth and ground vegetation, and repeated characterisations of soil condition every 10-20 years. The AFSCDB.LII.2.2 refers to the latest (second) soil survey. All assessments are executed following the ICP Forests Manual on Methods and Criteria for Harmonised Sampling, Monitoring and Analysis of the Effects of Air Pollution on Forests (ICP Forests 2006, 2010; Cools and De Vos 2013), which is regularly updated with regard to new methodological developments and field protocols.

\subsection{European supporting project}

Historically, information on soil condition was collected by the participating countries since 1993, when the European Commission for the first time supported a harmonised monitoring programme on Level II plots including a soil survey (European Commission 1994). The first Level II soil condition survey, carried out between 1993 and 1995, provides the reference for the second soil condition survey that started about 10-15 years later. The countries continued, standardised, and extended their soil assessments in the second soil condition survey during the BioSoil demonstration project within the EU project Forest Focus (Regulation (EC) No. 2152/2003 of the
European Parliament and of the Council on 17 November 2003 concerning monitoring of forests and environmental interactions in the Community, 2006-2007, 127 Level II plots) and the EU Life+ project FutMon (2009-2011, 118 Level II plots). During the BioSoil project, it was also possible to deliver formerly collected soil profile and horizon description information as long as the measurement criteria were met for a specific variable.

\subsection{Evolution of sampling design}

Soil sampling and analysis was carried out by national institutes in charge within the participating countries following the Manual on Sampling and Analysis of Soil in the versions valid in the respective years (Expert Panel on Soil and Forest Soil Coordinating Centre 2006; Cools and De Vos 2010 including the FutMon field protocol for the determination of soil water characteristics). The Forest Soil Coordinating Centre of ICP Forests (FSCC) processed all available Level II soil data after the second soil survey (predominantly BioSoil and FutMon data) and consolidated these data in a plotwise-aggregated format in the Aggregated Forest Soil Condition Database of the Level II 2nd soil survey version 1 (AFSCDB.LII.2.1, Cools and De Vos 2014), which provided the basis for the actually presented version 2 (AFSCDB.LII.2.2). The actual version was extended to include soil hydraulic properties and nutrient stocks and has undergone a number of additional checks and corrections.

\subsection{Database content}

Using standard soil profile descriptions (FAO 2006; Expert Panel on Soil and Forest Soil Coordinating Centre 2006) and analysed soil samples that were mainly gathered between 2003 and 2010 from 286 Level II plots, AFSCDB.LII.2.2 contains the main soil variables of the forest floor (noted OL and OFH layers on database), the horizons of the mineral soil, and fixed depth layers noted M01, M12, M24, M48 (resp. 0$10,10-20,20-40$, and $40-80 \mathrm{~cm}$ ) for mineral or peat soil. Supplementing this dataset, next to the aggregated soil data, the database contains derived soil variables that were calculated from raw data, e.g. base saturation, cation exchange capacity and $\mathrm{C}: \mathrm{N}$ ratios, nutrient stocks, field capacity, permanent wilting point, plant available water capacity, and the water retention parameters of the Mualem/van Genuchten model. The RETC code (RETention Curve code, van Genuchten et al. 1991), was used for separate approximations of the Mualem/ van Genuchten model to the observed soil water retention data series from each sample. A table of quality code is included in the database; it permits to trace back the applied methods, the quantification limits, and the ring-test proficiency of the laboratories that produced the analytical data (König et al. 2013). 


\section{Main features and potential use of the database}

Two aspects of the AFSCDB.LII.2.2 make it a unique database: Firstly, it applies a transnationally standardised methodology for comprehensive and quality controlled soil analyses to a large number of forest soils across Europe, and secondly, it combines this information with soil hydraulic properties related to the same dataset. On the 286 plots, 318 profiles have been dug, the database represents 2083 sampled pedogenetic horizons and 1480 fixed depth layer samples with up to 100 soil variables determined and documented from each sample. Geographical coverage of the database is well convenient, extending over $35^{\circ}$ of latitude from North to South and over $42^{\circ}$ of longitude from East to West (Cools and De Vos 2014). Plots cover nearly all member states of the European Union from Cyprus to Ireland and from Northern Finland to Southern Spain with a majority in Central Europe (Fig. 1).

As dominant characteristics of forest soils, the database contains the parent material, the humus type, the texture, the water retention capacity, and the availability of nutrients for forest growth. The following section provides a summarising description of these variables for the whole aggregated dataset.

\subsection{Parent material}

The most abundant soil parent material among the Level II plots is unconsolidated glacial deposits and glacial drift $(27 \%)$. It represents with unconsolidated and the eolian deposits about half of all plots considered. About $40 \%$ of plots are based on consolidated bedrock of different origin (igneous, consolidated-clastic-sedimentary, metamorphic, and sedimentary origin: 13, 10, 9, and $6 \%$, respectively). Only $2 \%$ of the plots are located on organic materials. For the remaining $12 \%$ of the plots, the parent material is unknown.

\subsection{Humus type}

Type and rate of organic material decomposition and its incorporation into the soil varies among forests due to different soil and climatic conditions (Zanella et al. 2011). Hence, the

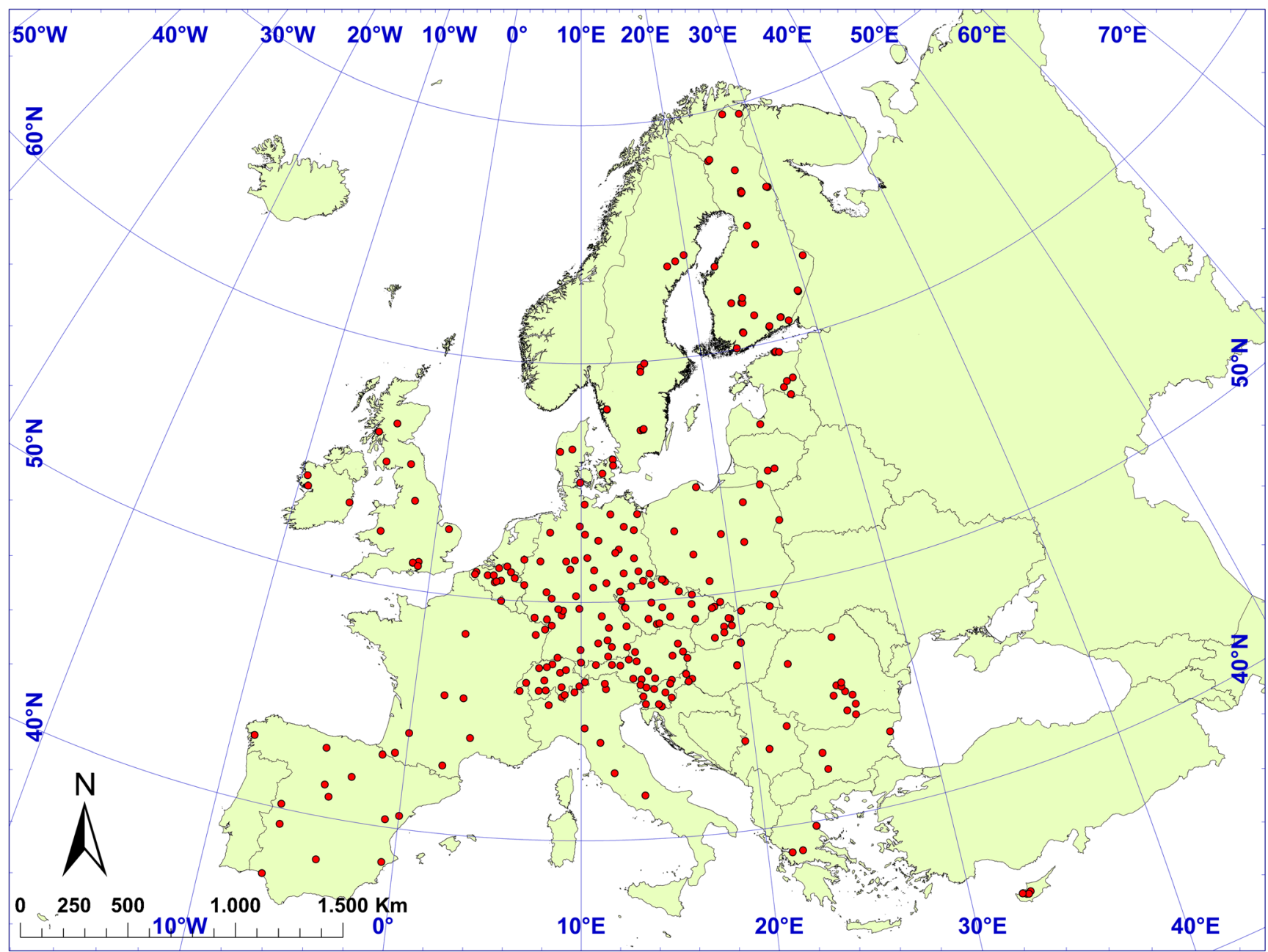

Fig. 1 Geographical distribution of Level II plots in the AFSCDB.LII.2.2 database 
humus type reflects the long-term development of these conditions and has a direct impact on nutrient availability. Moder is the dominant humus type on the Level II plots in the database (Fig. 2), occurring on about $30 \%$ of the plots. It is followed by Mor (26\%) and Mull (18\%). Rare humus types in the database are Histomor (3\%), Anmoor and Amphi ( $1 \%$ each). For $23 \%$ of the plots, the humus type is not yet available but is expected to be completed in future database versions.

\subsection{Texture class}

Some soil-derived properties are strongly dependent of soil texture, for example, soil porosity (Bruand and Cousin 1995), soil bulk density (De Vos et al 2005), and soil hydraulic characteristics (Saxton et al. 1986; Wösten et al. 2001; Toth et al. 2015). Depending on the fixed depth layer, this information is available for $60-80 \%$ of the plots. "Loam" is the most frequent texture class in the topsoil till $20 \mathrm{~cm}(20 \%$ of the plots), while "Sandy loam" is the most frequent texture class in the lower layers $(20-80 \mathrm{~cm}, 18-26 \%$, Fig. 3). "Sandy loam" is also the second most important texture class in the upper layers (about $18 \%$ ). The texture class "sand" is more often found in the subsoil below $20 \mathrm{~cm}$ depth than in the top soil, but this is the case for some of the clay dominated texture classes ("clay," "clay loam," and "silty clay") as well.

\subsection{Plant available water}

The soil water retention functions indicate the capacity of the soil to retain water against gravitation (field capacity). The water content at field capacity $(\mathrm{pF}=1.8)$ was on most plots between 25 and $35 \%$ of the soil volume, with minimum values around $5 \%$ and a maximum value above $70 \%$ (Fig. 4b). Values between 10 and $52 \%$ would be expected for Central European soils (AG Boden 2005), a range into which about $90 \%$ of the Level II plots in the database fall. By definition, the available water content (AWC) is the

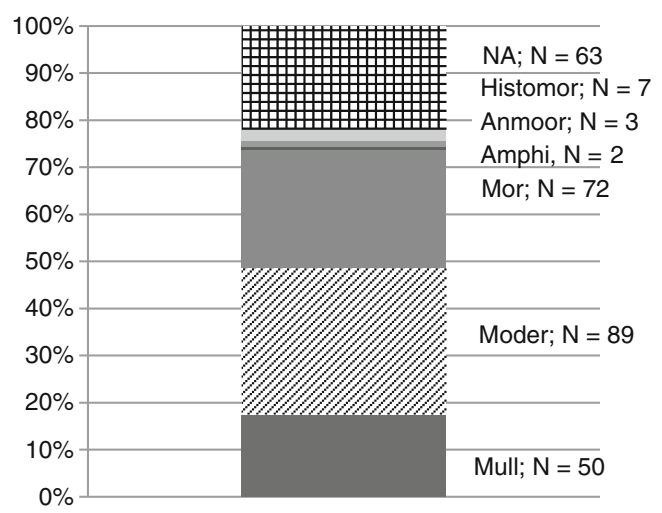

Fig. 2 Humus type of the European forest soils in the database

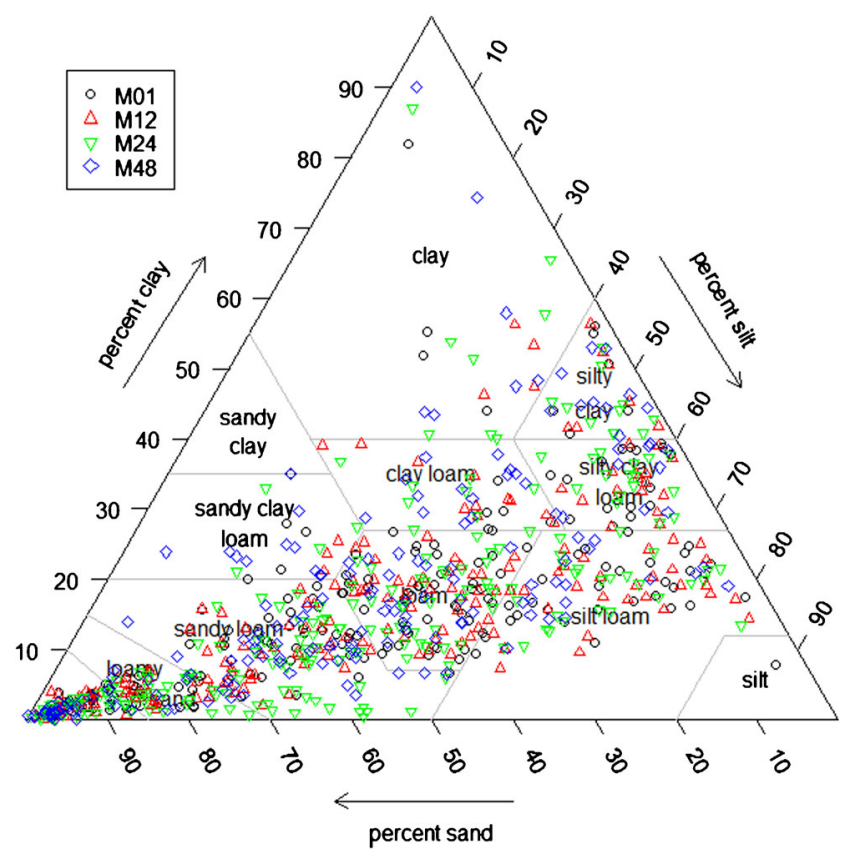

Fig. 3 Relative contribution of the different texture classes in four depth layers of European forest soils in the database: assessed mineral soil layers range from 0 to $10 \mathrm{~cm}$ (M01), 10 to $20 \mathrm{~cm}$ (M12), 20 to $40 \mathrm{~cm}$ (M24), and 40 to $80 \mathrm{~cm}$ (M48)

difference between the water contents at field capacity (FC) and permanent wilting point ( $\mathrm{PWP}, \mathrm{pF}=4.2$ ). For raw calculation without gravel content correction, most plots are included on 10 and $20 \%$ of the soil volume, ranging from 5 to $35 \%$ for $90 \%$ of the plots (Fig. 4c).

The analysis of soil water retention measurements was based on a conservative approach by applying approximations of the Mualem/van Genuchen function (van Genuchten et al. 1991) to the measured data using the software RETC. The stable S-form of this function guarantees a monotonically decreasing water content with decreasing matric potential and is not sensitive to measurement errors due to its limited flexibility. Unreliable or too scarce measurement results were excluded from the analysis. The use of RETC eliminates degrees of freedom in the approximation procedure as residual water content was always set to 0 and tortuosity to 0.5 . Samples for determination of soil water retention characteristics usually originated from three soil pits per plot. In many cases, one soil pit was identical to the pit for the description of the soil profile. Three samples were taken within each pit. Each soil water retention measurement series was approximated separately with the Mualem/van Genuchten function, so that up to 13 different soil water retention results were obtained from the replicate measurements within the same fixed depth layer of a plot. The soil water retention function with the plot- 
a

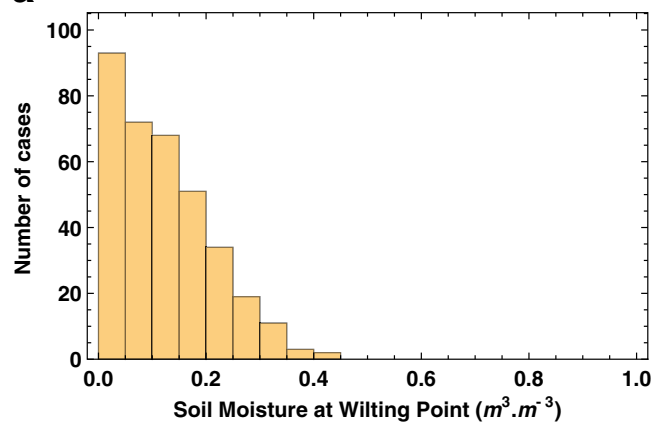

b

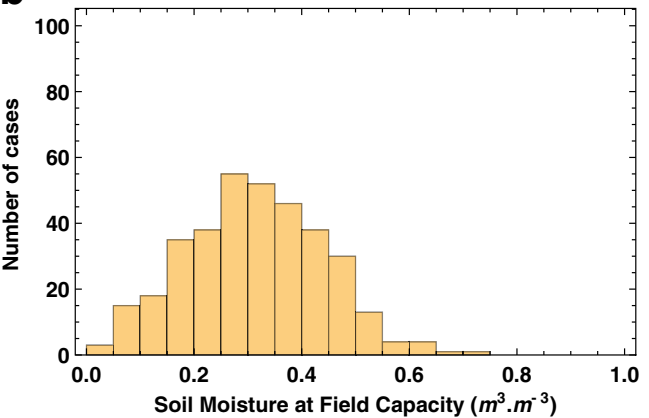

C

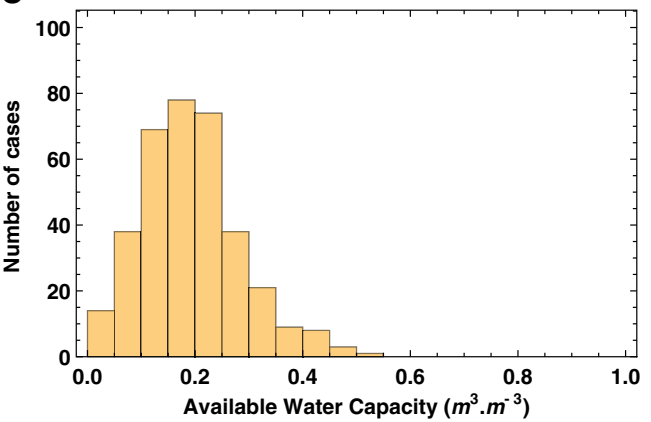

Fig. 4 Frequency distribution of soil moisture at permanent wilting point (a), soil moisture at field capacity (b), and available water content (c) over all fixed depth layers on all Level II plots in the database

representative Mualem/van Genuchten approximation was selected based on its $r^{2}$-value to all measurements on the plot for a given depth layer in order to derive the plot representative values.

\subsection{Nutrient stocks}

The database allowed to calculate nutrient stocks in forest floors and mineral soils which required organic layer mass, bulk density, coarse fragments, layer thickness, and soil depth in addition to the layer-based concentrations of $\mathrm{C}, \mathrm{N}, \mathrm{S}$, and P. The nutrient stocks of these elements were quantified using the same methods as applied in De Vos et al. (2015) for SOC stock estimations. Stock of an element in the forest floor was determined for each $\mathrm{OFH}$ and OL layer separately as the product of organic layer mass and the concentration of the element. The sum of both layers yielded the forest floor stock of the element. For stocks in mineral soil, first, we calculated for each depth fixed layer the nutrient density (in tons of nutrient/ha/cm of soil depth) incorporating bulk density and volume of coarse fragments. Secondly, we fitted on depth by using mass-preserving spline functions (Odgers et al. 2012). And thirdly, stocks in mineral soil were determined by integrating the nutrient density values from $0 \mathrm{~cm}$ to the reference depths of 30 and $100 \mathrm{~cm}$ or to effective soil depth (e.g. lithic contact, see De Vos et al. 2015). Spline functions were used to extrapolate nutrient density values from the maximum sampling depth of 80 to $100 \mathrm{~cm}$.

The average stocks in forest floors were $23 \mathrm{tC} \mathrm{ha}^{-1}$, $0.93 \mathrm{tN} \mathrm{ha}^{-1}, 0.052 \mathrm{tP} \mathrm{ha}^{-1}$, and $0.102 \mathrm{tS} \mathrm{ha}^{-1}$. The carbon stocks till $1 \mathrm{~m}$ depth (if soil was not shallower) ranged from 17 to roughly $400 \mathrm{tC} \mathrm{ha}^{-1}$ for $90 \%$ of the plots, reaching over $800 \mathrm{t} \mathrm{ha}^{-1}$ for peat soils (Fig. 5a). Most plots stored between 50 and $150 \mathrm{tC} \mathrm{ha}^{-1}$. Nitrogen stocks reached values up to $35 \mathrm{tN} \mathrm{ha}^{-1}$, with most plots lying in the range of 0.7 to $10 \mathrm{tN} \mathrm{ha}^{-1}$ (Fig. 5b). Phosphorous stocks were in most cases below $3 \mathrm{tP} \mathrm{ha}^{-1}$, reaching a maximum value of about $11 \mathrm{tP} \mathrm{ha}^{-1}$ (outlier: $24 \mathrm{tP} \mathrm{ha}^{-1}$ ) (Fig. 5c). Sulphur stocks could only be calculated on about half of the plots. They typically were in the range of $0.3-2 \mathrm{tS} \mathrm{ha}^{-1}$, with maximum values over $8 \mathrm{tS} \mathrm{ha}^{-1}$ (Fig. 5d).

\subsection{Reference soil group}

Despite the fact that AFSCDB.LII.2.2 covers almost all EU member states, it may not in all aspects provide representative information for European forest soils. When comparing with the Level I dataset as a geographically representative dataset for European forests, AFSCDB.LII.2.2 shows a generally similar distribution of world reference base (WRB) soil groups, but certain reference soil groups (Leptosols, Regosols, and Histosols) are underrepresented, while others (Luvisols, Podzols and Arenosols) are overrepresented in the dataset (Fig. 6).

\subsection{Tree species repartition}

Major differences are also visible with regard to tree species: While the major tree species on the Level I grid are Pinus sylvestris and Picea abies, with Fagus sylvatica and Quercus robur being much less abundant, AFSCDB.LII.2.2 contains mostly plots with $P$. abies as dominant tree species, followed by $P$. sylvestris and F. sylvatica, that cover almost similar shares of plots. The proportion of beech is twice as high as compared to Level I (Fig. 7). 
a

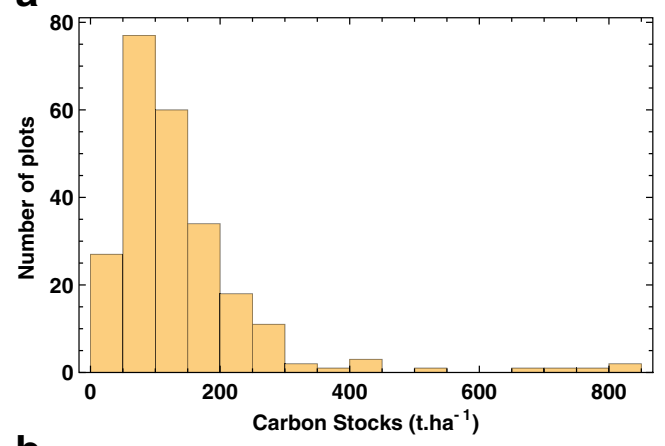

b

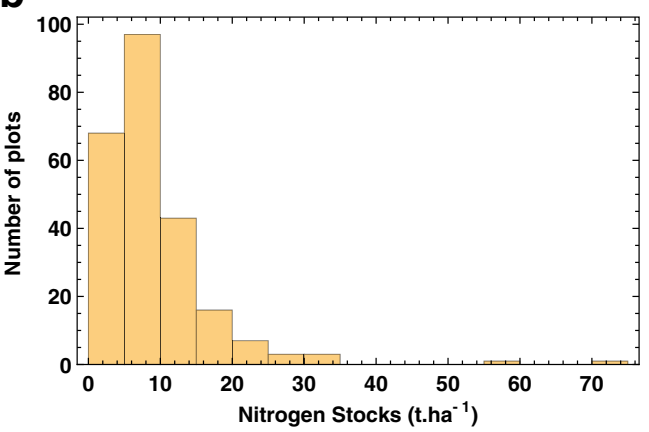

C

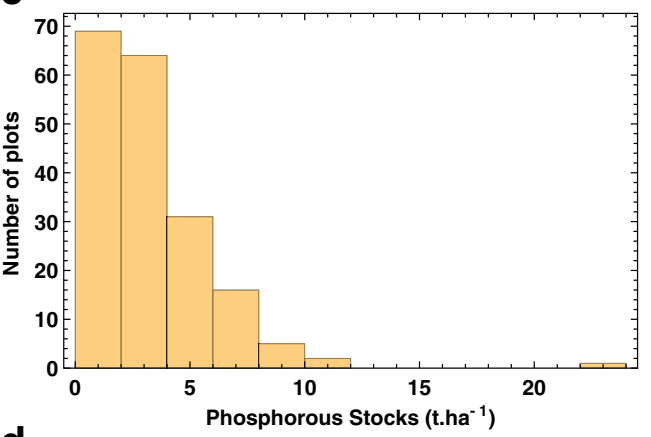

d

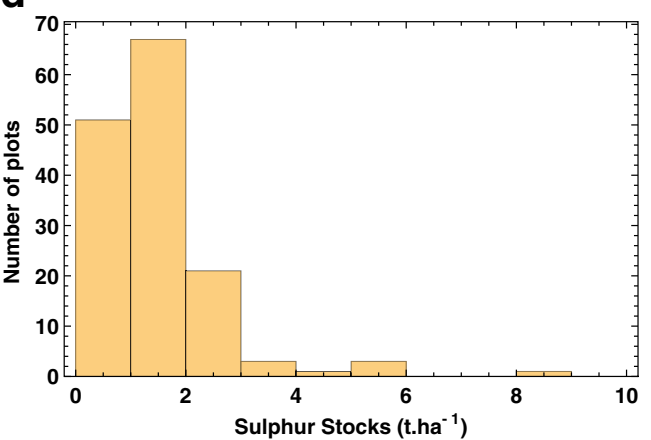

Fig. 5 Frequency distribution of the Level II plots considered for a stocks of carbon, $\mathbf{b}$ nitrogen, $\mathbf{c}$ phosphorous, and $\mathbf{d}$ sulphur

\subsection{Representativeness of database}

Scaling up of the results obtained on Level II to the European level may be mediated using the spatially systematic soil inventory on Level I, where similar definitions are applied in less intensive monitoring campaigns, comprising a limited set of parameters. Due to the partial non-representativeness of the AFSC Level II database in spatial terms, it is in many cases not adequate to use generalising statistical deduction methods based on the whole dataset. Instead, we recommend using upscaling methods based on the covariance between Level II and Level I variables to achieve larger spatial coverage. In those cases where statistical deduction methods are necessary, it is possible to use some kind of bias correction for the AFSCDB.LII.2.2 data, if the frequency distributions of the most sensitive variables at the target scale are available.

Reasons for the partial non-representativeness of the dataset with regard to tree species or soil type may be found in the criteria for the selection of the Level II plots (European Commission 1994). The plots had to be located in such a way that the more important forest tree species and more widespread growing conditions in the respective country were represented. The plots had to be easily accessible at all times and with limited restrictions for sampling and observations. Consequently, remote areas (such as boreal marshes, high-altitude mountains, and swamps) are underrepresented and with them those tree species and soil types that prevail in these areas. On the other hand, it was important to include forests with high vulnerability to acid deposition. Such forests usually grow on acid soils such as Podzols and Arenosols.

\subsection{Potentiality of database}

Many options are available to evaluate this database. First of all, the database provides an exhaustive set of soil variables that may be used to study relationships between different soil traits. Secondly, the large amount of chemical soil variables allows to investigate the fate and behaviour of substances drop off on the forest ecosystem (Ranger and Turpault 1999; Augustin et al. 2005; De Vries et al. 2007; Waldner et al. 2015). Thirdly, the data were obtained in a long-term monitoring programme providing time series of ecosystem variables. This offers many options for integrated evaluations of soil data with other temporal assessments on the same plots such as crown condition, foliar chemistry, or tree growth, allowing in-depth analyses with mechanistic models (e.g. van der Salm et al. 2007; Reinds et al. 2008; Jochheim et al. 2009; Mol Dijkstra et al. 2009) in order to better understand cause-effect relationships in forest processes and responses to environmental impacts (Lorenz and Fischer 2013).

A combination of the 286 plots with other surveys conducted in the forest monitoring programme shows good overlap with long time series of variables in the surveys of crown 
Fig. 6 Frequency distribution of WRB-soil groups in the AFSCDB LII 2.2 database compared to the systematic Level I grid

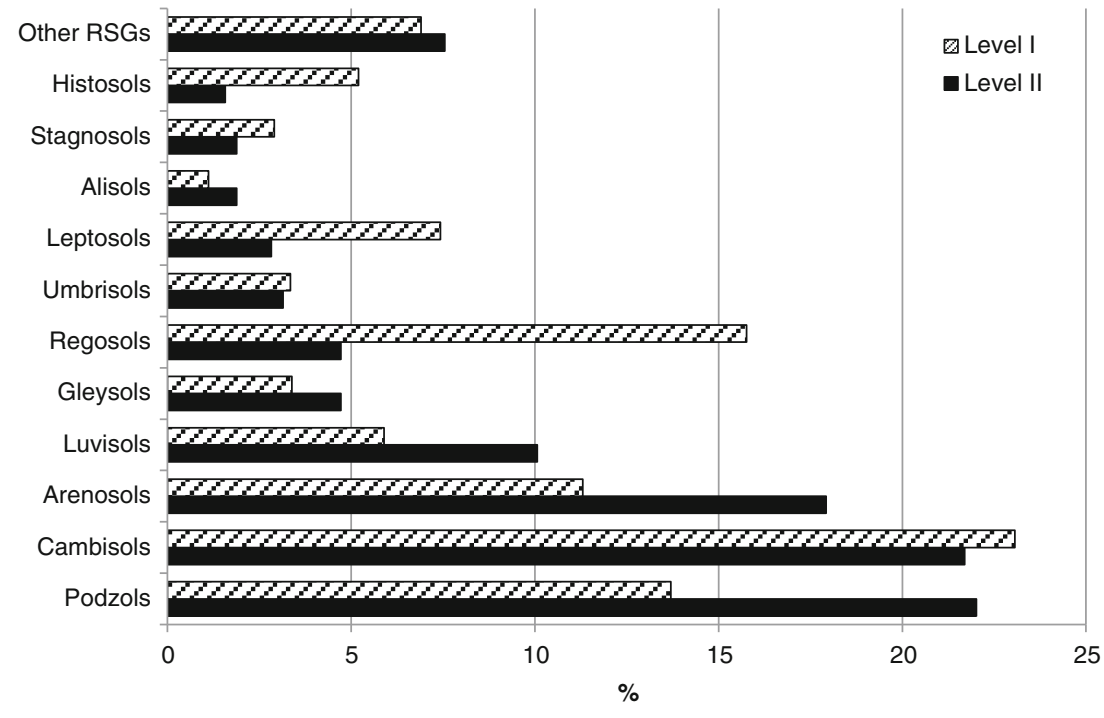

condition, foliar analyses, tree growth, deposition, and meteorological measurements (up to 200 plots available), and even the lowest overlap (survey on continuous soil moisture measurements) provides more than 40 plots for combined analysis with the aggregated soil data (Table 1). For this survey, there are additional data available via the national institutes participating in ICP Forests. Additional options emerge since the focus of ICP Forests broadened from air pollution impact on forests to a more integrated environmental monitoring programme for forests including biodiversity and climate change aspects. Due to continuous improvements, more parameters are assessed, providing new information for the same plots. Finally, since the soil survey at Level II plots follows the same manual as for Level I plots, the database offers additional options for spatially explicit upscaling on the European scale.

\section{Structure of the database and metadata}

\subsection{Database content}

The AFSCDB.LII.2.2 database contains both measurements from horizon-based sampling (up to 88 unique soil variables) and from fixed depth layer composite sampling (about 73 soil variables plus 14 variables on laboratory quality). In addition, 18 more variables describing soil water retention are related to both sampling strategies. All these variables are combined with explanatory variables like geographical location and date of sampling and analysis, so that they may be linked with other information collected on the same plots.

On each plot, horizon-based sampling, layer based sampling, or both have been performed. Up to three profiles were
Fig. 7 Distribution of species in the AFSCDB LII 2.2 dataset compared to Level I plots

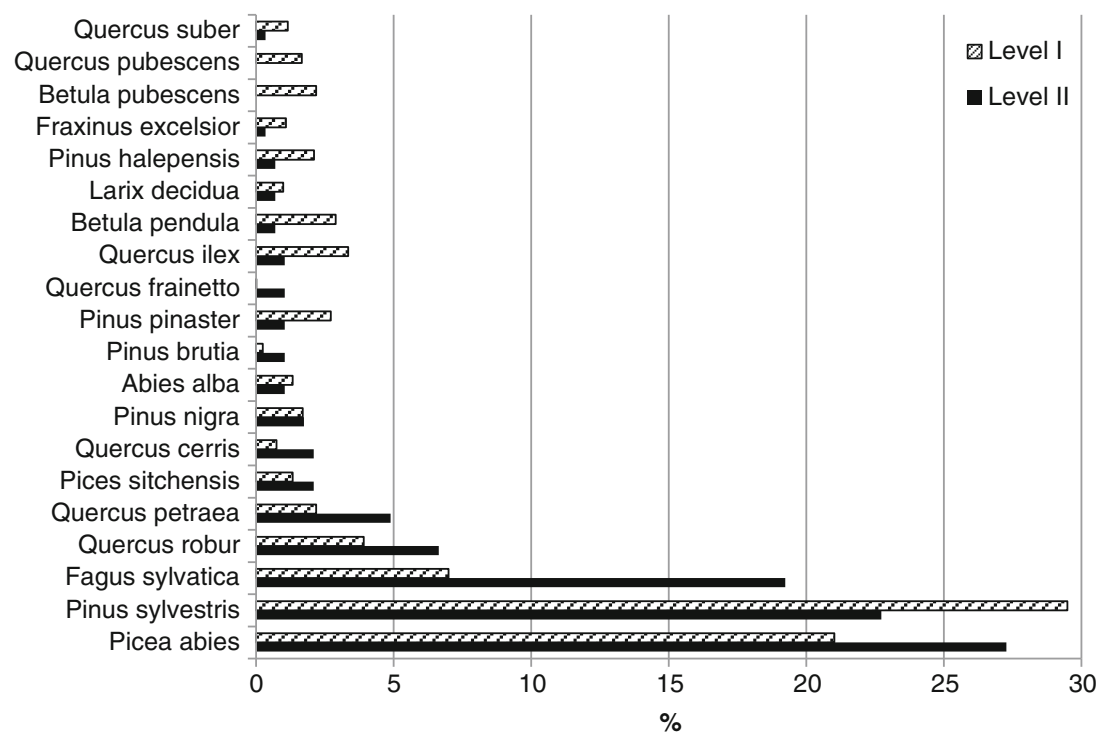


Table 1 Number of plots with coinciding aggregated soil data in the AFSCDB.II.2.2 and forest ecosystem monitoring data series till 2010

\begin{tabular}{|c|c|c|c|c|c|c|c|c|c|c|c|c|c|c|c|c|c|c|c|c|c|}
\hline Year & 90 & 91 & 92 & 93 & 94 & 95 & 96 & 97 & 98 & 99 & 00 & 01 & 02 & 03 & 04 & 05 & 06 & 07 & 08 & 09 & 10 \\
\hline Crown condition & 6 & 20 & 8 & 10 & 37 & 128 & 156 & 173 & 179 & 172 & 169 & 191 & 142 & 163 & 205 & 183 & 202 & 223 & 184 & 242 & 242 \\
\hline Foliar analysis & & 2 & 4 & 12 & 20 & 129 & 69 & 132 & 47 & 166 & 35 & 182 & 69 & 129 & 37 & 192 & 30 & 160 & 59 & 201 & 78 \\
\hline Deposition analysis & & 4 & 5 & 17 & 19 & 53 & 120 & 146 & 145 & 152 & 156 & 158 & 138 & 173 & 170 & 187 & 200 & 201 & 194 & 209 & 221 \\
\hline Growth and increment & & 16 & 9 & 16 & 45 & 58 & 63 & 34 & 10 & 81 & 83 & 11 & 11 & 18 & 87 & 92 & 20 & 20 & 22 & 159 & 50 \\
\hline Meteorology & & 2 & 3 & 3 & 4 & 12 & 43 & 69 & 77 & 98 & 103 & 99 & 92 & 100 & 111 & 111 & 130 & 134 & 129 & 178 & 176 \\
\hline Soil solution analysis & & 2 & 8 & 6 & 7 & 17 & 47 & 65 & 81 & 90 & 88 & 95 & 82 & 105 & 115 & 110 & 127 & 131 & 122 & 152 & 155 \\
\hline Ground vegetation & & & & & & 19 & 46 & 17 & 77 & 67 & 52 & 66 & 34 & 77 & 49 & 55 & 59 & 40 & 6 & 145 & 84 \\
\hline Air quality & & & & & & & & & & 1 & 21 & 21 & 56 & 55 & 57 & 40 & 64 & 77 & 87 & 144 & 137 \\
\hline Litterfall & & & & & & & & & & & & & 23 & 30 & 37 & 52 & 51 & 81 & 61 & 144 & 155 \\
\hline Phenology & & & & & & & & & & & & & 16 & 25 & 37 & 41 & 46 & 43 & 46 & 91 & 114 \\
\hline Ozone injury & & & & & & & & & & & & & 30 & 32 & 29 & 21 & 24 & 33 & 31 & 93 & 90 \\
\hline Leaf area index & & & & & & & & & & & & & & & & & & & & 95 & 133 \\
\hline Ground vegetation nutrients & & & & & & & & & & & & & & & & & & & & 89 & 74 \\
\hline Soil water content & & & & & & 1 & & & & & & & & & & & & & & 46 & 49 \\
\hline
\end{tabular}

classified per plot following IUSS WRB Working Group (2007). On $95 \%$ of the profiles, between 3 and 12 horizons were described following international reference guidelines (FAO 2006) and samples were taken for laboratory analysis.

The layer-based sampling comprises 1480 records (i.e. layers) with laboratory analyses performed on the composite samples taken at fixed depths. The median number of sampling points per plot was 24 , consisting of three replicates per layer with eight subsamples each. Data availability is best for the upper $10 \mathrm{~cm}$ of the soil profile and is decreasing with depth. The soil variables belong to the following categories (in parentheses: numbers of available horizon-specific/layerspecific variables): horizon or layer structure and designation $(31 / 4)$, parent material $(3 / 3)$, soil physics $(6 / 3)$, texture $(6 / 6)$, hydraulic properties $(10 / 10)$, groundwater $(4 / 5)$, international soil classification (13/13), humus layer (1/2), stocks of chemical compounds (3/23), exchangeable cations (13/15), extractable elements (2/18), and roots $(6 / 2)$. The explanatory variables refer to geographical-, plot-, and profile-related location of the measurements $(23 / 21)$, date of measurements and analyses (10/10), measurement method (14/16), and statistical or ring-test-based analytical quality of the results (12/13).

While not all of these variables are yet available for every single plot, it remains the ultimate objective of the ICP Forests community to complete and extend the dataset in coming versions of the database. The current database version is therefore available as a permanent archive via the ICP Forests programme-hosted repository. Updated versions will be added in the future.

\subsection{Derived data}

The layer-based dataset contains a number of derived soil variables such as the $C: N$ ratio, the sum of the basic (BCE) and acid exchangeable cations (ACE), the base saturation (BS), and the cation exchange capacity (CEC). In order to allow calculations with small concentrations below the limit of quantification (LOQ), they have been replaced by half the value of the median LOQ of all labs participating in the FSCC interlaboratory ring tests (Cools et al. 2003, 2006, 2007; Cools and De Vos 2009). The layer-based analytical results have been recalculated to obtain one layer-specific mean value per plot for each variable. Data availability is best for the soil variables $\mathrm{pH}-\mathrm{CaCl}_{2}$, organic carbon, and total nitrogen.

Nutrient stocks in forest floors could be quantified for 263 out of 286 Level II plots for C and N, and on 185 and 156 plots for $\mathrm{P}$ and $\mathrm{S}$ stocks, respectively. Carbon and nitrogen stocks in mineral soils were determined for 239 level II plots (84\%), P stocks on 188 plots (66\%) and S stocks on 147 plots (52\%).

Soil water retention characteristics (FC, AWC, and PWP) are layer representative and horizon representative. One thousand six hundred fifty-two measured $\mathrm{pF}$-curves were used to derive plot-representative soil water retention functions for 353 fixed depth intervals of 103 Level II plots.

\subsection{Quality control and assurance}

A limitation of the dataset may be seen in the fact that analyses were carried out by different national laboratories in Europe instead of one central lab. Even after detailed cross-checks of every variable, it cannot be excluded that there are still inconsistencies in the database. However, extensive ring test and training activities have been carried out during the soil survey and show convincing results (König et al. 2013). Furthermore, national labs are trained and specialised in the analysis of local soil types and have high experience in the interpretation and validation of the analytical results. Layer-based data submitted from the survey year 2009 onwards are accompanied by 
information on quality assurance and quality control (Tables 2 and 3). The laboratory methods are provided by a detailed coding system. Information on the within-laboratory quality programme is provided together with information on the performance of the laboratory for the concerning soil analytical variable in the FSCC interlaboratory ring tests.

\subsection{Recommendation database use}

The verification of database contents has been done as far as it was possible over years, and the remaining insecurity of the measured values is very small. However, we recommend to report singularities, i.e. unexpected relationships of single measurements that may only become visible in combined evaluations with other variables to the FSCC in order to verify the specific background of a certain measurement. This way, the database content can successively be brought to perfection and thereby profit from its use in research projects.

A goal in the database set-up was also to enable the users to directly access the original measured values. For this reason and since there are different preferences in the aggregation of results over several layers or horizons, it was explicitly avoided to establish fixed links between horizon-based quantities and layer-based quantities. The users themselves can establish this link in the way and with the preferences they need it, based on the available information to the measured extension of horizons or sampling depths. Also, in those cases of summarising variables, where the number of missing values was high, the user should decide how to treat this based on the specific needs of the actual evaluation.

\subsection{Organisation of database}

Figure 8 shows the relationships between tables of the database and the primary keys necessary to link tables:

Table 2 The number and type of soil layers contained in the dataset with the "sampling and analysis at fixed depths" (SOM) information

\begin{tabular}{llll}
\hline Code of layer & Depth of the layer & Mean thickness $(\mathrm{cm})$ & $\mathrm{N}^{\circ}$ layers \\
\hline OL & Variable & $1.7(0.5 ; 4)^{\mathrm{a}}$ & 190 \\
OFH & Variable & $4.1(1 ; 13)^{\mathrm{a}}$ & 244 \\
M01 & $0-10 \mathrm{~cm}$ & 10 & 254 \\
M12 & $10-20 \mathrm{~cm}$ & 10 & 253 \\
M24 & $20-40 \mathrm{~cm}$ & 20 & 241 \\
M48 & $40-80 \mathrm{~cm}$ & 40 & 204 \\
H01 & $0-10 \mathrm{~cm}$ & 10 & 6 \\
H12 & $10-20 \mathrm{~cm}$ & 10 & 6 \\
H24 & $20-40 \mathrm{~cm}$ & 20 & 5 \\
H48 & $40-80 \mathrm{~cm}$ & 40 & 1 \\
\hline
\end{tabular}

a $95 \%$ range
The horizon-specific measurements (table PFH) are always linked to their respective soil profile information (PRF) and to the plot information (PLS). Independent from that, layer-based sampling results (table SOM), which were made in a plot-representative way, are directly linked to the plot describing variables in PLS. An automated link between data from both sampling strategies is not possible, though it may be constructed by the user based on assumptions on the plot representativeness of the horizons described in the soil profile. The laboratory analytical quality variables (table LQA) refer to the layer-based measurements. The pF-curve data (SWA) from different profiles on the plot were taken in the most representative horizon of the respective depth interval and are, thus, linked to layer-based variables as well as to horizon variables. The same is true for the plotrepresentative soil water retention variables (SWR) that are based on the most representative $\mathrm{pF}$-curve for a given layer and horizon. The plot aggregated nutrient stocks (STO) are derived from layer-based variables along with profile information (e.g. effective soil depth) and relate directly to the plot information.

\subsection{Metadata}

Metadata to the whole database are given at https://metadataafs.nancy.inra.fr/geonetwork/apps/georchestra/?uuid=153 e599e-6624-4e2b-b862-8124386ea9cd\&hl=eng. The metadata file includes several tables: (1) a documentation on data provision and discovery, (2) information on the origin and context of the database, and (3) a technical documentation of the meaning of all variable names (short explanations) with automated links to their occurrence in the data table headlines and vice versa. Next to this, the eight soil data tables (PLS, PRF, PFH, SOM, STO, SWA, SWR, and LQA) are followed by 28 key code tables that provide a list of those values that coded variables may exhibit (e.g. altitude is classified as a coded variable exhibiting 51 possible values). Wherever the name of a coded variable appears, the key code tables are accessible via automated links.

Additional supplementary material comprises (1) a complete list of the tables in the database and the data format of their variables, (2) an entity relationship model of the database, and (3) a data dictionary.

The data dictionary provides the most exhaustive information on methodological aspects and original definitions of each variable at the time of measurement. It is a pdf file with automated text links to the relevant parts of most of the original manuals that were followed during the description, sampling, and analysis of the forest soils (PCC 2012; IUSS Working group WRB 2006, 2007; FAO 2006; Expert Panel on Soil and Forest Soil Coordinating Centre 2006; Cools and De Vos 2010; AG Boden 2005; König et al. 
Table 3 Number of aggregated data in the SOM dataset for the concerning variables and layers (OL, OFH, M01, M12, M24, M48) available on the 286 Level II plots contained in the AFSCDB.LII.2.2

\begin{tabular}{|c|c|c|c|c|c|c|c|c|c|c|c|c|c|}
\hline \multirow[b]{2}{*}{ Layer/variable } & \multicolumn{2}{|c|}{ Forest floor } & \multicolumn{4}{|c|}{ Fixed depth } & \multirow[b]{2}{*}{ Layer/variable } & \multicolumn{2}{|c|}{ Forest floor } & \multicolumn{4}{|c|}{ Fixed depth } \\
\hline & $\mathrm{OL}$ & $\mathrm{OFH}$ & M01 & M12 & M24 & M48 & & $\mathrm{OL}$ & $\mathrm{OFH}$ & M01 & M12 & M24 & M48 \\
\hline CLAY & & & 188 & 190 & 219 & 168 & BCE & 30 & 227 & 246 & 245 & 243 & 185 \\
\hline SILT & & & 188 & 190 & 219 & 168 & $\mathrm{ACE}$ & 26 & 216 & 242 & 241 & 239 & 182 \\
\hline SAND & & & 188 & 190 & 219 & 168 & CEC & 30 & 227 & 246 & 245 & 243 & 185 \\
\hline $\mathrm{BD}$ & & & 195 & 184 & 172 & 143 & $\mathrm{BS}$ & 30 & 227 & 246 & 245 & 243 & 185 \\
\hline BDEST & & & 27 & 29 & 29 & 28 & EXTRAL & 124 & 183 & 203 & 161 & 157 & 116 \\
\hline CFMASS & & & 67 & 62 & 62 & 24 & EXTRCA & 134 & 229 & 224 & 202 & 196 & 143 \\
\hline CFVOL & & & 188 & 186 & 171 & 172 & EXTRCD & 132 & 218 & 228 & 158 & 156 & 122 \\
\hline ORGLAY & 183 & 224 & & & & & EXTRCR & 120 & 191 & 204 & 158 & 157 & 116 \\
\hline PHCACL2 & 59 & 243 & 259 & 259 & 245 & 188 & EXTRCU & 133 & 230 & 246 & 173 & 169 & 127 \\
\hline PHH2O & 47 & 211 & 223 & 218 & 216 & 161 & EXTRFE & 131 & 203 & 222 & 169 & 166 & 124 \\
\hline $\mathrm{OC}$ & 130 & 242 & 260 & 259 & 244 & 187 & EXTRHG & 39 & 49 & 58 & 38 & 36 & 36 \\
\hline TON & 128 & 242 & 260 & 259 & 244 & 187 & EXTRK & 134 & 230 & 224 & 202 & 196 & 143 \\
\hline $\mathrm{CN}$ & 128 & 242 & 259 & 256 & 229 & 160 & EXTRMG & 134 & 230 & 224 & 202 & 196 & 143 \\
\hline EXCHACID & 25 & 213 & 237 & 235 & 233 & 174 & EXTRMN & 133 & 230 & 225 & 203 & 198 & 145 \\
\hline CARBONATES & 4 & 24 & 34 & 36 & 37 & 33 & EXTRNA & 107 & 178 & 196 & 148 & 146 & 104 \\
\hline EXCHAL & 26 & 212 & 242 & 241 & 238 & 181 & EXTRNI & 121 & 193 & 207 & 161 & 160 & 119 \\
\hline EXCHCA & 30 & 227 & 246 & 245 & 243 & 186 & EXTRP & 134 & 230 & 224 & 203 & 198 & 145 \\
\hline EXCHFE & 26 & 212 & 242 & 241 & 239 & 182 & EXTRPB & 133 & 230 & 246 & 172 & 169 & 127 \\
\hline EXCHK & 30 & 227 & 247 & 246 & 244 & 188 & EXTRS & 123 & 172 & 191 & 152 & 150 & 106 \\
\hline EXCHMG & 30 & 227 & 247 & 246 & 244 & 188 & EXTRZN & 133 & 230 & 246 & 171 & 167 & 125 \\
\hline EXCHMN & 30 & 223 & 247 & 246 & 244 & 188 & REACAL & 26 & 71 & 166 & 165 & 166 & 125 \\
\hline EXCHNA & 30 & 227 & 247 & 246 & 244 & 188 & REACFE & 26 & 71 & 166 & 165 & 166 & 125 \\
\hline FREEH & 27 & 218 & 243 & 242 & 239 & 182 & & & & & & & \\
\hline
\end{tabular}

Variables for particle size fractions, bulk density (BD), coarse fragments (CF), the organic layer's dry weight, pH values, organic carbon content (OC), total organic nitrogen (TON), carbonates, exchangeable cations, and extractable elements are considered in this table

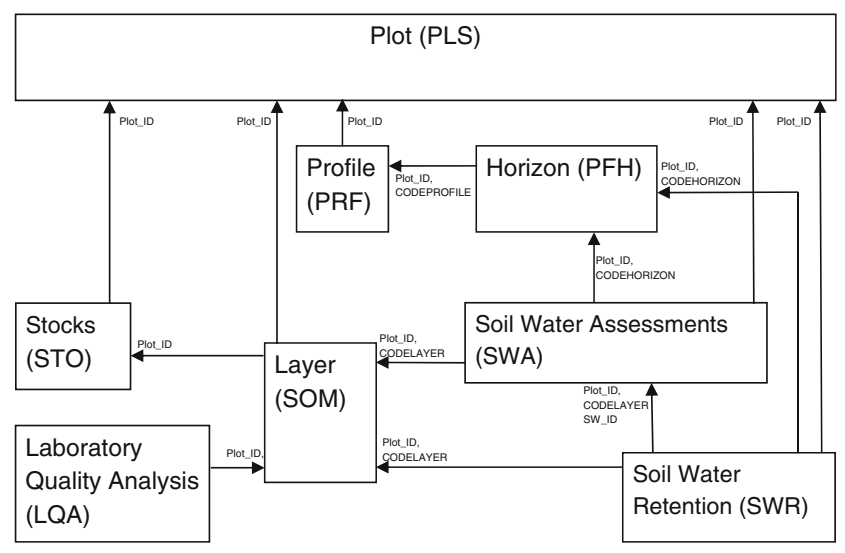

Fig. 8 Relationships between the data tables in the database. Horizonspecific properties (PFH) are linked to profile descriptions (PRF) on the plots (PLS), while the plot-representative results from layer-based sampling (SOM) as well as the nutrient stock calculations (STO) relate directly to the plots (PLS). The plot-representative soil water retention properties (SWR) and the data for their derivation (SWA) relate to data from both sampling strategies. Deeper insights in the relationships between tables are available in electronic supplementary material format
2010). References are given to those manuals where important other information originates from (Finke et al. 2001; Munsell 1975).

\section{Data access and data policy}

The database is archived at the Programme Co-ordinating Centre (PCC) of ICP Forests in Eberswalde, Germany. Access to these aggregated data can be requested via the official project homepage: http://icp-forests.net. Under the menu "Plots and data - data requests" the official data request form is provided. The requesting part has to provide an abstract on the scientific purpose and approach to PCC, which will be evaluated by the ICP Forests Expert Panel on Soil and Soil Solution (e-mail: FSCC@inbo.be). A positive evaluation will usually imply the condition to invite one or more of the authors of the database to collaborate in the use of the data. For data usage in announced collaboration with the expert panel, PCC will 
usually provide the database within a few days (maximum 2 weeks after submission of the data request).

\section{Conclusions}

A main advantage of the database is the accessibility of detailed soil information that was sampled in a harmonised way over such a large and fragmented area as Europe. A lack of such detailed and harmonised information had been identified by several studies (Köhl et al. 2000; De Vries et al. 2007; Morvan et al. 2008; Clarke et al. 2011; Danielewska et al. 2013). A specific asset is the combination of physicochemical and structural soil variables with laborious-to-measure soil hydraulic properties, which enables the investigation of pedotransfer functions for soil hydraulic characteristics (Wösten et al. 2001; Teepe et al. 2003).

The combination of these soil data with long-term time series of various other forest ecosystem variables measured on the same plots makes this database an interesting source of information for integrated forest ecosystem studies (Ferretti et al. 2014; De Vries et al. 2014). The comprehensive picture of processes and state variables in a forest that may be provided this way is indispensable for a quantitative understanding of ecosystem processes based on ecosystem models: Statistical models can be validated with time series over more than 10 years in most cases. The application of parameterdemanding mechanistic and dynamic ecosystem models is possible as well as the calibration or validation of nondynamic models. Even the slow dynamics behind soil models (e.g. carbon balance models) may be validated by a combination with older data, since the data of the first soil survey that took place between 1989 and 1995 are available for 184 of the 286 plots. Every year of further assessments on each of the common plots extends these possibilities due to longer time series. It is this kind of quantitative understanding that enables forest researchers to estimate the responses of forest ecosystems to changing climate, pollution, and other conditions that may be expected for the future.

Upscaling of results from the evaluation of AFSCDB.LII.2.2 information to the forested area of Europe is possible using the spatially representative Level I information. This enables proper upscaling approaches using e.g. tree species or soil groups as stratification criteria.

Based on the enhanced efforts for quality control and assurance, we believe that this dataset reaches an unprecedented degree and quality of harmonisation of forest soil data. We hope this aggregated soil database will be widely used, and we encourage the users to report eventual errors or inconsistencies to the FSCC in order to improve database quality. Future updates of this aggregated soil database are also planned to include externally derived data.
Acknowledgments We wish to acknowledge the ICP Forests National Focal Centres of Austria, Belgium, Bulgaria, Czech Republic, Cyprus, Denmark, Estonia, Finland, France, Germany, Greece, Hungary, Ireland, Italy, Latvia, Lithuania, Poland, Romania, Slovenia, Slovak Republic, Spain, Sweden, Switzerland, and the UK for making the soil survey data available to the Programme Coordinating Centre of ICP Forests and to FSCC for analysis and evaluation at the European level. We thank all participants of the Expert Panel on Soil and Soil Solution for their active discussions and contributions in setting up the survey, the methods, and the quality control of the data. We thank Till Kirchner (PCC) and Nils König (NW-FVA) for their specific support during the preparation of this publication and beyond.

Special acknowledgements are due to the FAO for having allowed to reproduce, in the companion data dictionary file, the whole or part of manuals: (1) Food and Agriculture Organization of the United Nations (2006) IUSS Working Group WRB. World reference base for soil resources 2006. World Soil Resources Reports 103. ftp://ftp.fao. org/docrep/fao/009/a0510e/a0510e00.pdf3; (2) Food and Agriculture Organization of the United Nations (2007) IUSS Working Group WRB. World reference base for soil resources 2006. First update 2007. World Soil Resources Reports 103. http://www.fao. org/fileadmin/templates/nr/images/resources/pdf_documents/wrb2007_ red.pdf; and (3) Food and Agriculture Organization of the United Nations (2006) Jahn, R, Blume, H-P, Asio, VB, Spaargaren, O, Schad, P, Langohr, R, Brinkman, R, Nachtergaele, FO, Krasilnikov, RP. Guidelines for Soil Description and Classification, 4th edition. ftp://ftp.fao. org/agl/agl1/docs/guidel_soil_descr.pdf.

Funding Financial support for the data collection was granted by the European Commission through Commission Regulation (EEC) No. 926/ 93, the European Commission Forest Focus Regulation (EC) No. 2152/2003, and the Life+ co-financing instrument of DG Environment, funding the project "Further Development and Implementation of an EUlevel Forest Monitoring System (FutMon)."

Open Access This article is distributed under the terms of the Creative Commons Attribution 4.0 International License (http:// creativecommons.org/licenses/by/4.0/), which permits unrestricted use, distribution, and reproduction in any medium, provided you give appropriate credit to the original author(s) and the source, provide a link to the Creative Commons license, and indicate if changes were made.

\section{References}

Augustin S, Bolte A, Holzhausen M, Wolff B (2005) Exceedance of critical loads of nitrogen and sulphur and its relation to forest conditions. Eur J For Res 124:289-300

Boden AG (2005) Bodenkundliche Kartieranleitung. Bundesanstalt für Geowissenschaften und Rohstoffe, Hannover

Bruand A, Cousin I (1995) Variation of textural porosity of a clay-loam soil during compaction. Eur J Soil Sci 46:377-385

Clarke N, Fischer R, de Vries W, Lundin L, Papale D, Vesala T, Merilä P, Matteucci G, Mirtl M, Simpson D, Paoletti E (2011) Availability, accessibility, quality and comparability of monitoring data for European forests for use in air pollution and climate change science. iForest - Biogeosciences and Forestry 4:162-166

Cools N, De Vos B (2009) 6th FSCC Interlaboratory Comparison 2009. INBO.R.2010. Forest Soil Coordinating Centre, Research Institute for Nature and Forest, Geraardsbergen, 52 pages + annexes (on CD-Rom)

Cools N, De Vos B (2010) Sampling and Analysis of Soil. Manual Part X, $208 \mathrm{pp}$. In: Manual on methods and criteria for harmonized sampling, assessment, monitoring and analysis of the effects of air 
pollution on forests, UNECE, ICP Forests, Hamburg. ISBN: 978-3926301-03-1. http://www.icp-forests.org/Manual.htm

Cools N, De Vos B (2013) Forest soil: characterization, sampling, physical and chemical analyses. In: Ferretti M, Fischer R (eds) Forest monitoring methods for terrestrial investigations in Europe with an overview of North-America and Asia. Elsevier, Amsterdam

Cools N, De Vos B (2014) A harmonised level II soil database to understand processes and changes in forest condition at the European level. Technical Report, Thünen Institute, Eberswalde. http://icpforests.net/page/icp-forests-technical-report

Cools N, Delanote V, De Vos B et al (2003) Quality assurance and quality control in forest soil analysis: 3rd FSCC interlaboratory comparison. Forest Soil Coordinating Centre, Institute for Forestry and Game Management, Geraardsbergen, $301 \mathrm{p}$

Cools N, Verschelde P, Quataert P et al (2006) Quality assurance and quality control in forest soil analysis: 4th FSCC interlaboratory comparison. INBO.R.2006.6. Forest Soil Coordinating Centre, Research Institute for Nature and Forest, Geraardsbergen, Belgium. 66 pages + annexes (on CD-Rom).

Cools N, Mikkelsen JH, De Vos B (2007) Quality assurance and quality control in forest soil analysis: 5th FSCC interlaboratory comparison. INBO.R.2007.46. Forest Soil Coordinating Centre, Research Institute for Nature and Forest, Geraardsbergen, 59 pages + annexes (on CD-Rom)

Danielewska A, Clarke N, Olejnik J, Hansen K, Vries W, Lundin L, Tuovinen J, Fischer R, Urbaniak M, Paoletti E (2013) A meta-database comparison from various European research and monitoring networks dedicated to forest sites. iForest - Biogeosciences and Forestry 6:1-9

De Vos B, van Meirvenne M, Quataert P, Deckers J, Muys B (2005) Predictive quality of pedotransfer functions for estimating bulk density of forest soils. Soil Sci Soc Am J 69:500-510

De Vos B, Cools N, Ilvesniemi H, Vesterdal L, Vanguelova E, Carnicelli S (2015) Benchmark values for forest soil carbon stocks in Europe: results from a large scale forest soil survey. Geoderma 251-252:33-46

De Vries W, Kros H, Reinds GJ, Wamelink GWW, Mol Dijkstra JP, van Dobben HF, Bobbink R, Emmett B, Smart SM, Evans C, Schutlow A, Kraft P, Belyazid S, Sverdrup H, van Hinsberg A, Posch M, Hettelingh J-P (2007) Developments in deriving critical limits and modeling critical loads of nitrogen for terrestrial ecosystems in Europe. Alterra-rapport, Alterra, Wageningen

De Vries W, Dobbertin MH, Solberg S, van Dobben HF, Schaub M (2014) Impacts of acid deposition, ozone exposure and weather conditions on forest ecosystems in Europe: an overview. Plant Soil 380:1-45

European Commission (1994) Commission regulation (EC) No 1091/94 of 29 April 1994 laying down certain detailed rules for the implementation of Council Regulation (EEC) No 3528/86 on the protection of the Community's forests against atmospheric pollution. Official Journal of the European Union (OJ) EUR-Lex L series 125, 18.5.1994, p 1-81

Expert Panel on Soil, Forest Soil Coordinating Centre (2006) Sampling and analysis of soil. Manual Part IIIa. In: Manual on methods and criteria for harmonised sampling, assessment, monitoring and analysis of the effects of air pollution on forests. UNECE, ICP Forests, Hamburg, 94 pp. http://icp-forests.org/Manual.htm

FAO (2006) Guidelines for soil description and classification, 4th edn. Food and Agriculture Organisation of the United Nations, Rome

Ferretti M, Calderisi M, Marchetto A, Waldner P, Thimonier A, Jonard M, Cools N, Rautio P, Clarke N, Hansen K, Merilä P, Potocic N (2014) Variables related to nitrogen deposition improve defoliation models for European forests. Ann For Sci 72:897-906. doi:10.1007/s13595-0140445-6

Finke P, Hartwich R, Dudal R, Ibàñez J, Jamagne M, King D, Montanarella L, Yassoglou N (2001) Georeferenced soil database for Europe. Manual of Procedures. Version 1.1. Edited by European Soil Bureau Scientific Committee, Research Report N5. EUR 18092 EN
ICP Forests (2006) Manual on methods and criteria for harmonised sampling, assessment, monitoring and analysis of the effects of air pollution on forests. UNECE, ICP Forests. Hamburg http://www.icpforests.org/Manual.htm

ICP Forests (2010) Manual on methods and criteria for harmonized sampling, assessment, monitoring and analysis of the effects of air pollution on forests. UNECE, ICP Forests, Hamburg. http://www.icpforests.org/Manual.htm

IUSS Working Group WRB (2006) World reference base for soil resources 2006. World Soil Resources Reports. No. 103. FAO, Rome

IUSS Working Group WRB (2007) World reference base for soil resources 2006, first update 2007. World Soil Resources Reports. No. 103. FAO, Rome

Jochheim H, Puhlmann M, Beese F, Berthold D, Einert P, Kallweit R, Konopatzky A, Meesenburg H, Meiwes K-J, Raspe S, SchulteBisping H, Schulz C (2009) Modelling the carbon budget of intensive forest monitoring sites in Germany using the simulation model BIOME-BGC. iForest - Biogeosciences and Forestry 2:7-10

Köhl M, Traub B, Päivinen R (2000) Harmonisation and standardisation in multi-national environmental statistics - mission impossible? Environ Monit Assess 63:361-380

König N, Kowalska A, Brunialti G, Ferretti M, Clarke N, Cools N, Derome J, Derome K, De Vos B, Fuerst A, Jakovljevič T, Marchetto A, Mosello R, O'Dea P, Tartari GA, Ulrich E (2010) Quality Assurance and Control in Laboratories. 53 pp. Part XVI. In: Manual on methods and criteria for harmonized sampling, assessment, monitoring and analysis of the effects of air pollution on forests. UNECE, ICP Forests Programme Coordinating Centre, Hamburg. ISBN: 978-3-926301-03-1. http://www. icp-forests.org/Manual.htm

König N, Cools N, Derome K, Kowalska A, De Vos B, Fürst A, Marchetto A, O'Dea P, Tartari GA (2013) Data quality in laboratories: methods and results for soil, foliar, water, and chemical analyses. In: Ferretti M, Fischer R (eds) Forest monitoring: methods for terrestrial investigations in Europe with an overview of North America and Asia. Elsevier, Oxford, pp 19-32

Lorenz M, Fischer R (2013) Pan-European forest monitoring: an overview. In: Ferretti M, Fischer R (eds) Forest monitoring: methods for terrestrial investigations in Europe with an overview of North America and Asia. Elsevier, Oxford, pp 19-32

Mol Dijkstra JP, Reinds GJ, Kros H, Berg BÂ, de Vries W (2009) Modelling soil carbon sequestration of intensively monitored forest plots in Europe by three different approaches. For Ecol Manag 258: $1780-1793$

Morvan X, Saby NPA, Arrouays D, Le Bas C, Jones RJA, Verheijen FGA, Bellamy PH, Stephens M, Kibblewhite MG (2008) Soil monitoring in Europe: a review of existing systems and requirements for harmonisation. Sci Total Environ 391:1-12

Munsell (1975) Munsell Soil Color Book, Munsell.com

Odgers NP, Libohova Z, Thompson JA (2012) Equal-area spline functions applied to a legacy soil database to create weighted-means maps of soil organic carbon at a continental scale. Geoderma 189 190:153-163

PCC (Project Coordinating Center of ICP Forests) (2012) Forms and explanatory items to be applied for data submission from 2011 onwards, Version 2011n6, 30th October 2012. Thünen Institute, Eberswalde

Ranger J, Turpault M-P (1999) Input-output nutrient budgets as a diagnostic tool for sustainable forest management. For Ecol Manag 122: $139-154$

Reinds GJ, van Oijen M, Heuvelink GBM, Kros H (2008) Bayesian calibration of the VSD soil acidification model using European forest monitoring data. Geoderma 146:475-488

Saxton KE, Rawls WJ, Romberger JS, Papendick RI (1986) Estimating generalized soil-water characteristics from texture. Soil Sci Soc Am J 50:1031-1036 
Teepe R, Dilling H, Beese F (2003) Estimating water retention curves of forest soils from soil texture and bulk density. J Plant Nutr Soil Sci 166:111-119

Toth B, Weynants M, Nemes A, Mako A, Bilas G, Toth G (2015) New generation of hydraulic pedotransfer functions for Europe. Eur J Soil Sci 66:226-238

Van der Salm C, Reinds GJ, de Vries W (2007) Water balances in intensively monitored forest ecosystems in Europe. Environ Pollut 148: 201-212

Van Genuchten TM, Leij FJ, Yates SR (1991) The RETC code for quantifying the hydraulic functions of unsaturated soils. USDA, Riverside, California

Waldner P, Thimonier A, Graf Pannatier E, Etzold S, Schmitt M, Marchetto A, Rautio P, Derome K, Nieminen TM, Nevalainen S, Lindroos A-J, Merilä P, Kindermann G, Neumann M, Cools N, de
Vos B, Roskams P, Verstraeten A, Hansen K, Pihl Karlsson G, Dietrich H-P, Raspe S, Fischer R, Lorenz M, Iost S, Granke O, Sanders TGM, Michel A, Nagel H-D, Scheuschner T, Simončič P, von Wilpert K, Meesenburg H, Fleck S, Benham S, Vanguelova E, Clarke N, Ingerslev M, Vesterdal L, Gundersen P, Stupak I, Jonard M, Potočić N, Minaya M (2015) Exceedance of critical loads and of critical limits impacts tree nutrition across Europe. Ann For Sci 72: 929-939. doi:10.1007/s13595-015-0489-2

Wösten JHM, Pachepsky YA, Rawls WJ (2001) Pedotransfer functions: bridging the gap between available basic soil data and missing soil hydraulic characteristics. J Hydrol 251:123-150

Zanella A, Jabiol B, Ponge JF, Sartori G, De Waal R, Van Delft B, Graefe U, Cools N, Katzensteiner K, Hager H, Englisch M (2011) A European morphofunctional classification of humus forms. Geoderma 164:138-145 